\title{
Efek Pemberian Blondo dalam Ransum terhadap Total Koloni Lactobacillus sp, Salmonella sp dan Escherichia coli pada Ileum Broiler
}

\section{Effect of Feeding By-Product of Virgin Coconut Oil Processing (Blondo) on Total Colony Lactobacillus sp, Salmonella sp and Escherichia coli in Illeum of Broiler}

\author{
E. Martinelly, Husmaini, E. Purwati R.N., R. Zein, dan R. M. Siagian \\ Fakultas Peternakan Universitas Andalas, \\ Kampus Unand Limau Manis Padang 25163 \\ E-mail: (Diterima: 14 Oktober 2010; Disetujui: 03 Januari 2011)
}

\begin{abstract}
An experiment was conducted to study the effect of feeding by-product from virgin coconut oil processing (blondo) in ration on total colony of Lactobacillus sp, Salmonella sp and Escherichia coli in ileum of broiler. Broilers reared for 6 weeks in Unit Pelaksana Teknis (UPT), at Faculty of Animal Science, University of Andalas. One hundred of broilers strain Cobb on three days old were used. The design of experiment was a Completely Randomized Design (CRD), with 5 treatments $(0 ; 7.5 ; 15 ; 22.5$ and $30 \%$ blondo level in ration) and 4 replications for each treatment. Variables observed were total colony of Lactobacillus sp bacteria, Salmonella sp and Escherichia coli in ileum of broiler at 3 and 6 weeks of age. The result showed, total colony of Lactobacillus sp bacteria highly significant $(P<0.01)$ increased and Salmonella sp highly significant $(P<0.01)$ decreased by treatment at 3 and 6 weeks of age, but only decreased significantly $(P<0.05)$ total colony of Escherichia coli bacteria at 3 weeks of age and highly significant decreased $(P<0.01)$ at 6 weeks of age. The results showed that administration of $15 \%$ blondo in ration showed the most aptimal results in creating a balance of microflora in ileum of broiler.
\end{abstract}

Keywords: Broiler, blondo, total colony bacteria, illeum

\section{PENDAHULUAN}

Broiler merupakan salah satu ternak unggas yang memiliki peran cukup penting diantara ternak penghasil daging di Indonesia. Berdasarkan data yang dirilis oleh Direktorat Jenderal Peternakan (2008), populasi broiler saat ini sekitar 075.884 .785 ekor dan menyumbang sekitar $51 \%$ terhadap produksi daging nasional.

Kendala terbesar dalam pembesaran broiler adalah tingginya biaya pakan, mencapai $70 \%$ dari biaya produksi, sehingga peternak selalu berusaha mencari bahan pakan alternatif yang dapat menekan biaya produksi ke tingkat yang lebih rendah.

Blondo merupakan salah satu bahan pakan alternatif yang mulai tersedia saat ini, yaitu produk limbah industri pertanian sisa pembuatan minyak kelapa murni yang disebut Virgin Coconut Oil (VCO). Potensi blondo antara lain memiliki kandungan protein, mineral dan energi yang cukup tinggi. Selain itu blondo juga mengandung asam lemak tak jenuh rantai sedang, antara lain asam oleat (omega-9), asam linoleat (omega-6) dan linolenat (omega-3). Purwati et al., (2006) melaporkan, bahwa dalam blondo basah terdapat Lactobacillus. Hasil prapenelitian di Laboratorium Ke sehatan Ternak Fakultas Peternakan Universitas Andalas menunjukkan, setelah mengalami pengeringan dengan cara penjemuran, jumlah Lactobacillus di dalam blondo $103 \times 10^{6} \mathrm{CFU} / \mathrm{g}$. Hal ini memungkinkan Lactobacillus dapat berfungsi sebagai probiotik untuk memelihara kesehatan dan meningkatkan daya tahan tubuh ayam.

Saarella et al., (2000) dan Surono (2004) menyatakan, pemberian probiotik dapat berpengaruh positif bagi kesehatan karena probiotik menghasilkan senyawa-senyawa seperti asam laktat dan asetat yang menyebabkan suasana usus menjadi asam serta $\mathrm{H}_{2} \mathrm{O}_{2}$ dan bakteriosin yang memberikan efek antagonis terhadap pertumbuhan bakteri patogen sehingga menekan pertumbuhan dan patogenitas bakteri tersebut.

Menurut Haryanto (2005), bakteri yang paling banyak digunakan sebagai probiotik adalah golongan Lactobacillus. Golongan bakteri ini 
memiliki hampir semua karakteristik yang diperlukan sebagai probiotik. Lactobacillus juga dapat menurunkan $\mathrm{pH}$ lingkungan dengan mengubah gula menjadi asam laktat. Kondisi ini akan menghambat pertumbuhan beberapa jenis bakteri patogen.

Penyerapan makanan pada ayam terjadi di usus halus (duodenum, yeyunum, ileum). Ileum adalah bagian akhir dan paling panjang dari usus halus dan secara spesifik bertanggungjawab terhadap absorpsi vitamin $B_{12}$ dan reabsorpsi garam empedu konyugasi (conyugated bile salts). Sembilan puluh persen garam empedu konyugasi diserap di ileum (Encyclopedia Britannica Online, 2010).

Mikroflora usus memegang peranan penting dalam kesehatan ternak melalui pengaruhnya terhadap morfologi usus, nutrisi, patogenitas dari penyakit-penyakit intestinal dan respon imun. Flora mikrobial juga dipercaya mampu melindungi usus dari kolonisasi bakteri patogen dan merangsang sistem imun (Mead, 2000; dalam Lu et al., 2003). Berbagai tipe bakteri anaerobik yang jumlahnya sekitar $10^{9}$ hingga $10^{11}$ bakteri $\mathrm{g}^{-1}$ terdapat secara normal pada saluran pencernaan ternak ayam (Sjofjan, 2010). Jenis bakteri fakultatif anaerobik yang paling banyak ditemukan di ileum adalah Lactobacillus, 33\% di ileum bagian atas dan $59 \%$ di ileum bagian bawah (Salanitro et al., 1978). Namun banyak faktor dapat mempengaruhi komposisi komunitas bakteri pada ayam seperti makanan, umur, pemberian antibiotik dan infeksi oleh organisme patogen (Knarreborg, 2002; dalam Lu et al., 2003). Masuknya probiotik dalam saluran pencernaan ayam merupakan hal yang baru sehingga akan bereaksi dan memberikan dampak terhadap interaksi natural dan kompleks dari ekosistem mikroflora yang sebelumnya sudah terbentuk (Sjofjan, 2010).

Berdasarkan uraian di atas, penelitian ini bertujuan untuk melihat apakah pemberian blondo dalam berbagai level dapat mempertahankan keseimbangan mikroflora di dalam ileum sehingga ileum dapat menjalankan fungsinya sebagaimana mestinya.

\section{MATERI DAN METODE}

Penelitian ini menggunakan 100 ekor broiler strain Cobb berumur 3 hari. Broiler dipelihara dalam kandang baterai individu berukuran $75 \times 60$ $x 70 \mathrm{~cm}$. Ransum yang digunakan diaduk sendiri, terdiri dari jagung kuning, dedak halus, tepung ikan, bungkil kedelai, bungkil kelapa, minyak kelapa, tepung tulang dan blondo yang telah dikeringkan.

Ransum perlakuan disusun iso protein $22 \%$ dan iso energi $3000 \mathrm{kkal} / \mathrm{kg}$ ransum. Air minum diberikan ad libitum. Komposisi ransum, kandungan zat-zat makanan dan energi metabolis ransum disajikan pada Tabel 1 .

Tabel 1.Komposisi bahan makanan (\%)

\begin{tabular}{lcrrrr}
\hline \multirow{2}{*}{ Komposisi Bahan Makanan } & \multicolumn{5}{c}{ Perlakuan } \\
\cline { 2 - 6 } & \multicolumn{1}{c}{$\mathrm{A}$} & $\mathrm{B}$ & $\mathrm{C}$ & $\mathrm{D}$ & $\mathrm{E}$ \\
\hline Jagung Kuning & 56,80 & 53,25 & 43,20 & 32,30 & 23,00 \\
Dedak Halus & 2,40 & 4,00 & 9,50 & 16,50 & 12,50 \\
Tepung Ikan & 12,50 & 12,50 & 12,50 & 12,50 & 12,50 \\
Bungkil Kedele & 17,60 & 14,25 & 11,30 & 7,70 & 4,50 \\
Bungkil Kelapa & 7,00 & 7,00 & 7,00 & 7,00 & 7,00 \\
Blondo Jemur & 0 & 7,50 & 15,00 & 22,50 & 30,00 \\
Tepung Tulang & 1,50 & 1,50 & 1,50 & 1,50 & 1,50 \\
Minyak Kelapa & 2,20 & 0 & 0 & 0 & 0 \\
\hline & 100 & 100 & 100 & 100 & 100 \\
\hline
\end{tabular}

Sumber : Hasil analisa labor nutrisi Fakultas Peternakan Unand (2007)

Tabel 2. Kandungan zat makanan dan energi metabolis ransum perlakuan

\begin{tabular}{lcrrrr}
\hline \multirow{2}{*}{ Komposisi Bahan Makanan } & \multicolumn{5}{c}{ Perlakuan } \\
\cline { 2 - 6 } & \multicolumn{1}{c}{$\mathrm{A}$} & $\mathrm{B}$ & $\mathrm{C}$ & $\mathrm{D}$ & $\mathrm{E}$ \\
\hline Protein & 22,00 & 21,98 & 22,08 & 22,01 & 22,00 \\
Lemak & 5,55 & 4,70 & 5,86 & 7,00 & 8,17 \\
Ca & 0,93 & 0,93 & 0,95 & 0,96 & 0,97 \\
P & 0,56 & 0,56 & 0,60 & 0,64 & 0,67 \\
ME & 2992,18 & 2985,78 & 3007,45 & 3012,14 & 3042,06 \\
\hline
\end{tabular}

Sumber : Hasil analisa labor nutrisi Fakultas Peternakan Unand (2007) 
Rancangan percobaan yang digunakan dalam penelitian ini adalah Rancangan Acak Lengkap (RAL) dengan 5 perlakuan dan 4 ulangan. Perlakuan yang diberikan adalah tingkat pemberian blondo dalam ransum, yaitu : $\mathrm{A}=0 \%, \mathrm{~B}=7,5 \%, \mathrm{C}=15 \%, \mathrm{D}=$ $22,5 \%$ dan $\mathrm{E}=30 \%$ blondo dalam ransum.

Peubah yang diamati adalah: total koloni bakteri Lactobacillus sp, Salmonella $s p$ dan Escherichia coli dalam ileum ayam broiler. Data yang diperoleh dianalisis ragam sesuai dengan rancangan yang digunakan dan diuji lanjut dengan Duncan's Multiple Range Test menurut Steel dan Torrie (1995).

\section{HASIL DAN PEMBAHASAN}

Rataan total koloni Lactobacillus $s p$ di ileum menurut masing-masing perlakuan disajikan pada Tabel 2. Hasil analisis keragaman menunjukkan, bahwa peningkatan pemberian blondo jemur dalam ransum sangat nyata meningkatkan $(\mathrm{P}<0,01)$ total koloni bakteri Lactobacillus $s p$ pada umur 3 dan 6 minggu.

Untuk kedua tingkat umur, total kolonibakteri mengalami peningkatan pada perlakuan A-C, tetapi kembali mengalami penurunan pada perlakuan $\mathrm{D}$ dan E. Meningkatnya total koloni dari A-C karena intake blondo yang juga meningkat. Hal ini dimungkinkan, karena meskipun konsumsi ransum antara A-Champir $\operatorname{sama}(A=2945,58 \mathrm{~g} ; B=2920,55 \mathrm{~g}$ dan $C=2816,46 \mathrm{~g})$, namun karena level blondo yang semakin meningkat, menyebabkan intake blondo juga meningkat $(\mathrm{A}=0 \mathrm{~g}$; $\mathrm{B}=219,04 \mathrm{~g}$ dan $\mathrm{C}=422,47 \mathrm{~g}$ ). Blondo mengandung Lactobacillus sp yang bersifat probiotik. Lactobacillus $s p$ yang tumbuh membentuk koloni di dalam usus menggunakan nutrien yang ada untuk menghasilkan metabolitberupa asam laktat.

Menurut Saarela et al., (2000) dan Surono (2004), bakteri asam laktat mempunyai enzim $\beta$ galaktosidase dan lactate dehidrogenase yang menghasilkan asam laktat dari glukosa. Karena suasana usus menjadi asam, Lactobacillus $s p$ mampu bertahan dan membentuk koloni baru.

Hal ini sesuai dengan hasil penelitian Manin et al., (2004) yang mendapatkan, bahwa dengan suasana asam pada saluran pencernaan bakteri probiotik mampu melewati saluran pencernaan unggas dengan $\mathrm{pH}$ 3,0-5,5, sementara bakteri patogen tidak mampu untuk hidup lama dan memperbanyak sel. Menurut Salanitro (1978), bakteri fakultatif anaerobik seperti Lactobacillus dapat mengontrol populasi bakteri fakultatif anaerobik lainnya dan bakteri-bakteri patogen di usus halus.

Pemberian blondo dengan level 22,5\% (D) dan $30 \%$ (E) menyebabkan penurunan kembali total koloni bakteri Lactotobacillus sp. Hal ini disebabkan kadar lemak blondo jemur yang juga semakin meningkat $(\mathrm{D}=7,0 \% ; \mathrm{E}=8,17 \%)$. Lemak yang terkandung di dalam blondo dimetabolisme oleh Lactobacillus s $p$ dan menghasilkan oksigen, sehingga menekan pertumbuhannya sendiri karena bakteri Lactobacillus $s p$ adalah bakteri anaerob. Widodo (2003) menjelaskan, keberadaan oksigen sangat menekan perkembangan bakteri asam laktat(BAL).

Rataan total koloni Salmonella $s p$ pada ileum ayam broiler disajikan pada Tabel 3. Hasil analisis keragaman menunjukkan, pemberian beberapa level blondo dalam ransum sangat nyata $(\mathrm{P}<0,01)$ menurunkan total koloni bakteri Salmonella sp. Penurunan terendah terdapat pada perlakuan C (15\%), karena total koloni Lactobacillus $s p$ yang paling tinggi juga terdapat pada perlakuan ini.

Seperti dikemukakan oleh Murni (2006), semakin besar kekuatan koloni /dosis Lactobacillus $s p$ yang digunakan maka semakin besar pula daya hambat terhadap pertumbuhan bakteri Salmonella $s p$, karena senyawa-senyawa inhibitor yang

Tabel 3. Rataan total koloni bakteri Lactobacillus sp pada illeum ayam broiler umur 3 dan 6 minggu (x $10^{7} \mathrm{CFU} / \mathrm{g}$ )

\begin{tabular}{ccc}
\hline Perlakuan & \multicolumn{2}{c}{ Umur } \\
\cline { 2 - 3 }$(\%)$ & 3 minggu & 6 minggu \\
\hline A & $12,25^{\mathrm{E}}$ & $6,75^{\mathrm{D}}$ \\
$\mathrm{B}$ & $35,50^{\mathrm{DCb}}$ & $102,25^{\mathrm{Ba}}$ \\
C & $85,50^{\mathrm{A}}$ & $132,75^{\mathrm{A}}$ \\
$\mathrm{D}$ & $56,50^{\mathrm{B}}$ & $84,25^{\mathrm{Bb}}$ \\
$\mathrm{E}$ & $42,00^{\mathrm{Ca}}$ & $56,00^{\mathrm{C}}$ \\
SE & $2,06^{2}$ & 4,73 \\
\hline
\end{tabular}

Keterangan : Superskrip berbeda pada kolom yang sama menunjukkan berbeda nyata $(\mathrm{P}<0,01)$ $(\mathrm{A}=0 \%, \mathrm{~B}=7,5 \%, \mathrm{C}=15 \%, \mathrm{D}=22,5 \%, \mathrm{E}=30 \%)$ 
dihasilkan Lactobacillus sp seperti asam laktat, asam asetat, $\mathrm{H}_{2} \mathrm{O}_{2}$ dan bakteriosin akan menyebabkan penurunan pertumbuhan bakteri Salmonella sp.

Bakteriosin (Saarela et al., 2000 dan Surono, 2004) adalah suatu peptida yang berifat bakteristatik dan bakteriosidal. Keberadaan mikroflora pathogen di dalam usus halus merupakan competitor bagi inang dalam hal pengambilan makanan dan menurunkan pencernaan lemak dan vitamin-vitamin yang larut dalam lemak karena efek dekonyugasi dari asam empedu (Engberg, 2000, dalam Falaki, 2010). Menurut Fuller (2002) dan Utomo (2002), keseimbangan mikroflora usus akan tercapai apabila mikroba yang menguntungkan dapat menekan mikroba yang merugikan, dimana mikroba patogen yang merugikan didesak keluar dari saluran pencernaan oleh mikroba yang menguntungkan.

Keseimbangan ini dapat tercapai apabila perbandingan antara mikroba yang menguntungkan terhadap mikroba yang merugikan adalah sebesar $85 \%$ : 15\% (Philip, 1993) atau 80\% : 20\% (Manap, 1998). Pada perlakuan C $(15 \%)$, perbandingannya adalah $81 \%: 19 \%$ padaumur 3 minggudan $94 \%: 6 \%$ padaumur 6 minggu.

MeningkatnyakembalitotalkoloniSalmonellasppada perlakuan $\mathrm{D}$ dan $\mathrm{E}$ disebabkan penurunan Lactobacillus $s p$ pada perlakuan yang sama/ Dengan berkurangnya jumlah koloni bakteri Lactobacillus sp, maka suasana $\mathrm{pH}$ usus akan menjadi basa, dan ini sangatcocokuntukpertumbuhan bakteri Salmonella $s p$. Rataan total koloni E. coli pada ileum ayam broilerumur3dan6minggudapatdilihatpadaTabel 4 .
Hasil analisis keragaman menunjukkan, bahwa pemberian blondo sampai $30 \%$ dalam ransum nyata $(\mathrm{P}<0,05)$ menurunkan total koloni $E$. coli pada umur 3 minggu dan sangat nyata $(\mathrm{P}<0,01)$ menurunkan total koloni bakteri yang sama pada umur 6 minggu, Trend penurunan juga sama dengan yang terjadi pada bakteri Salmonella $s p$, yaitu terendah pada perlakuan $\mathrm{C}(15 \%)$.

Bakteriosin (Saarela et al., 2000 dan Surono, 2004) adalah suatu peptida yang berifat bakteristatik dan bakteriosidal. Keberadaan mikroflora patogen di dalam usus halus merupakan kompetitor bagi inang dalam hal pengambilan makanan dan menurunkan pencernaan lemak dan vitamin-vitamin yang larut dalam lemak karena efek dekonyugasi dari asam empedu (Engberg, 2000, dalam Falaki, 2010). Menurut Fuller (2002) dan Utomo (2002), keseimbangan mikroflora usus akan tercapai apabila mikroba yang menguntungkan dapat menekan mikroba yang merugikan, dimana mikroba patogen yang merugikan didesak keluar dari saluran pencernaan oleh mikroba yang menguntungkan.

Keseimbangan ini dapat tercapai apabila perbandingan antara mikroba yang menguntungkan terhadap mikroba yang merugikan adalah sebesar $85 \%$ : 15\% (Philip, 1993) atau 80\% : 20\% (Manap, 1998). Pada perlakuan C $(15 \%)$, perbandingannya adalah $81 \%: 19 \%$ pada umur 3 minggu dan $94 \%$ : $6 \%$ pada umur 6 minggu.

Tabel 4. Rataan total koloni bakteri Salmonella sp pada ileum ayam broiler umur 3 dan 6 minggu (x10 $\mathrm{CFU} / \mathrm{g}$ )

\begin{tabular}{ccc}
\hline Perlakuan & \multicolumn{3}{c}{ Umur } \\
\cline { 2 - 3 }$(\%)$ & 3 minggu & 6 minggu \\
\hline A & $93,00^{\mathrm{A}}$ & $97,50^{\mathrm{A}}$ \\
B & $29,75^{\mathrm{B}}$ & $25,75^{\mathrm{Cb}}$ \\
C & $19,75^{\mathrm{CEb}}$ & $8,50^{\mathrm{D}}$ \\
D & $24,00^{\mathrm{BCD}}$ & $39,25^{\mathrm{Ca}}$ \\
E & $27,00^{\mathrm{BCa}}$ & $60,00^{\mathrm{B}}$ \\
SE & 1,98 & 4,73 \\
\hline
\end{tabular}

Keterangan : Superskrip berbeda pada kolom yang sama menunjukkan berbeda nyata $(\mathrm{P}<0,01)$ $(A=0 \%, B=7,5 \%, C=15 \%, D=22,5 \%, E=30 \%)$

Tabel 5. Rataan total koloni bakteri Escherichia coli pada ileum ayam broiler umur 3 dan 6 minggu (x10 7 CFU/g)

\begin{tabular}{ccc}
\hline \multirow{2}{*}{ Perlakuan (\%) } & \multicolumn{2}{c}{ Umur } \\
\cline { 2 - 3 } & 3 minggu & 6 minggu \\
\hline A & $28,00^{\mathrm{A}}$ & $34,75^{\mathrm{BCa}}$ \\
B & $27,72^{\mathrm{A}}$ & $18,25^{\mathrm{Db}}$ \\
$\mathrm{C}$ & $12,50^{\mathrm{BCbc}}$ & $6,5^{\mathrm{E}}$ \\
$\mathrm{D}$ & $15,75^{\mathrm{Bb}}$ & $32,00^{\mathrm{C}}$ \\
E & $22,75^{\mathrm{ABa}}$ & $57,25^{\mathrm{A}}$ \\
SE & 1,94 & 2,10 \\
\hline
\end{tabular}

Keterangan : Superskrip berbeda pada kolom yang sama menunjukkan berbeda nyata $(\mathrm{P}<0,01)$

( $A=0 \%, B=7,5 \%, C=15 \%, D=22,5 \%, E=30 \%)$

Efek Pemberian Blondo pada Broiler (E. Martinelly, et al.) 
Meningkatnya kembali total koloni Salmonella $S p$ pada perlakuan D dan E disebabkan penurunan Lactobacillus $s p$ pada perlakuan yang sama/ Dengan berkurangnya jumlah koloni bakteri Lactobacillus $s p$, maka suasana $\mathrm{pH}$ usus akan menjadi basa, dan ini sangat cocokuntukpertumbuhan bakteriSalmonellasp.

Rataan total koloni E. coli pada ileum ayam broiler umur 3 dan 6 minggu dapat dilihat pada Tabel 4 . Hasil analisis keragaman menunjukkan, bahwa pemberian blondo sampai $30 \%$ dalam ransum nyata $(\mathrm{P}<0,05)$ menurunkan total koloni $E$. coli pada umur 3 minggu dan sangat nyata $(\mathrm{P}<0,01)$ menurunkan total koloni bakteri yang sama pada umur 6 minggu, Trend penurunan juga sama dengan yang terjadi pada bakteri Salmonella sp, yaitu terendah pada perlakuan C $(15 \%)$.

Pemyataan ini juga ditunjang oleh Purwati dan Syukur (2005), bahwa Lactobacillus yang dikenal sebagai bakteribaik dapatmembunuhbakterijahat $E$. coli (tergolong bakteri Enterobacteriacea) karena menghasilkan bakteriosin. Meningkatnya kembali total koloni E. colipada perlakuan $\mathrm{D}(22,5 \%)$ dan $\mathrm{E}(30 \%)$ disebabkan menununnya Lactobacilluspadaperlakuanyangsama.

\section{KESIMPULAN}

Berdasarkan hasil penelitian dapat disimpulkan, bahwa pemberian blondo sampai level $15 \%$ dalam ransum dapat mempertahankan keseimbangan mikroflora dalam ileum karena Lactobacillus yang ada di dalam blondo dapat meningkatkan total koloni Lactobacillus $s p$ dan menurunkan total koloni bakteri Salmonella $s p$ serta total koloni $E$. coli pada ileum ayam broiler umur 3 dan 6 minggu. Disarankan untuk memberikan blondo sebesar $15 \%$ dalam ransum karena memperlhatkan hasil yang paling optimal dalam menciptakan keseimbanganmikroflorausus.

\section{DAFTAR PUSTAKA}

Direktorat Jenderal Peternakan, 2008. Buku Statistik Peternakan. Direktorat Jenderal Peternakan, Departemen Pertanian, Jakarta.

Falaki, M., M.S. Shargh, B. Dastar, S. Zerehdaran, and M. Khomairi, 2010. The investigation of intestinal micro-flora and growth response of young broiler given feed supplemented with different levels of probiotic and prebiotic. Journal of Animal and Veterinary Advances vol. 9, page 2685-2690.

Encyclopedia Britannica Online, 2010. Ileum. <http; // www. Britannica. Com>. Accessed: Dec. 18, 2010, 14.31 .

Haryanto, R. 2005. Antara Antibiotika, Probiotik dan Prebiotik. Asisten mobil lab Basic
Science Center ITB, Bandung.

Lu, J., U. Idris, B. Harmon, C. Hofacre, J.J Maurer, and M.D. Lee, 2003. Diversity and succession of intestinal bacterial community of the maturing broiler chicken. Applied and Environmental Microbiolgy. 6816-6824.

Manin, F., E. Hendalia, Yatno dan I.P. Kompiang. 2004. Potensi Bacillus circulans dan Bacillus $s p$ isolat saluran pencernaan itik lokal kerinci sebagai sumber probiotik. Jurnal Peternakan dan Lingkungan, vol. 10 (01): 12-20.

Murni, Y. 2006. Kajian potensi Lacto-bacillus $s p$. dari blondo (waste product virgin cocnut oil) sebagai probiotik. Skripsi. Fakultas MIPAUniversitas Andalas, Padang.

Purwati, E., dan S. Syukur, 2005. Aplikasi VCO untuk anti mikroba patogen. Dalam: Prosiding Biologi untuk Kesejahteraan Manusia dari Molekuler hingga Lingkungan. Seminar Nasional dan Kongres Biologi XIII, 16-17 September, Yogyakarta.

Purwati, E., Husmaini, S. Syukur, Y. Murni, dan Othman. 2006. Lactobacillus sp. Isolasi dari Blondo Virgin Coconut Oil Efektif Sebagai Probiotik. Proceding Seminar Hasil Hasil Penelitian Ilmu-ilmu Pertanian BKS Wilayah Barat. Jambi, 26-28 April 2006.

Saarela, M., G. Mogensen, R. Fonden, J. Malto, and T.M. Sandholm, 2000. Probiotic bacteria: savety, functional and technological properties. J. Biotech 84 : 197-215.

Salanitro, J.P, I.G. Blake, P.A. Muirhead, M. Maglio, and J.R. Goodman, 1978. Bacteria isolated from duodenum, ileum and cecum of young chicks. Applied and Enviromental Microbiolgy. 782-790.

Steel, R.G.D dan J.H Torrie. 1995. Prinsip dan Prosedur Statistika suatu Pendekatan Biometrik. Gramedia, Jakarta.

Surono, I.S., 2004. Probiotik, Susu Fermentasi dan Kesehatan. PTTRICK, Jakarta.

Syah, A.N. 2005. Virgin Coconut Oil Minyak Kelapa Penakluk Berbagai Aneka Penyakit. PT. Agromedia Pustaka, Bogor.

Sjofjan, O. 2010. Probiotik untuk Unggas, Dalam: Probiotik: Basis Ilmiah, Aplikasi dan Aspek Praktis. Editor: Soeharsono. Widya Padjadjaran, Bandung.

Widodo, A.D. 2003. Bioteknologi Industri Susu. Cetakan ke-1. Lacticia Press, Yogyakarta.

Efek Pemberian Blondo pada Broiler (E. Martinelly, et al.) 